\title{
PENGARUH MODEL INKUIRI TERBIMBING BERBASIS BLENDED LEARNING TERHADAP KEMAMPUAN KOGNITIF-PSIKOMOTOR PADA MATERI LARUTAN PENYANGGA
}

\author{
Sri Wardani ${ }^{1^{*}}$ dan Laksmita Firdaus ${ }^{1}$ \\ ${ }^{1}$ Jurusan Kimia FMIPA Universitas Negeri Semarang, Gedung D6 Lantai 2 Kampus Sekaran \\ Gunungpati Semarang, 50229, Indonesia \\ *Email: menuksriwardani@mail.unnes.ac.id
}

\begin{abstract}
ABSTRAK
Penemuan konsep materi pembelajaran secara mandiri dapat mempengaruhi kemampuan kognitif dan psikomotor peserta didik. Hasil observasi di SMAN 1 Karangtengah Demak menunjukkan bahwa pembelajaran masih berpusat pada guru sehingga kemampuan peserta didik dalam menemukan sendiri konsep materi masih kurang, hal ini menyebabkan rendahnya kemampuan kognitif dan psikomotor. Untuk menghindari hal tersebut diperlukan model pembelajaran yang sesuai yaitu inkuiri terbimbing. Guru belum menerapkan pembalajaran berbasis internet yang dapat membentuk sikap mandiri pada peserta didik, sehingga diperlukan pembelajaran berbasis internet seperti blended learning. Penelitian ini bertujuan untuk mengetahui pengaruh penerapan inkuiri terbimbing berbasis blended learning terhadap kemampuan kognitif dan psikomotor peserta didik kelas XI MIPA SMAN 1 Karangtengah Kabupaten Demak. Metode penelitian yang digunakan adalah eksperimen dengan pengambilan sampel menggunakan teknik cluster random sampling, diperoleh kelas XI MIPA 1 sebagai kelas eksperimen dan XI MIPA 4 sebagai kelas kontrol. Pengambilan data yang dilakukan dengan metode tes dan observasi. Analisis data awal menunjukkan kedua kelas berdistribusi normal dan memiliki varians sama. Rata-rata hasil tes kemampuan kognitif peserta didik kelas eksperimen sebesar 71,14 dan kelas kontrol sebesar 67,35. Rata-rata ketercapaian ranah psikomotor berdasarkan lembar observasi praktikum kelas eksperimen sebesar 79,9\% dan kelas kontrol 74,43\%. Besar pengaruh inkuiri terbimbing berbasis blended learning terhadap kemampuan kognitif dan psikomotor melalui uji koefisien determinasi sebesar 10,62\%. Berdasarkan hasil penelitian dapat disimpulkan bahwa penerapan model inkuiri terbimbing berbasis blended learning berpengaruh terhadap kemampuan kognitif dan psikomotor peserta didik kelas XI pada materi larutan penyangga.
\end{abstract}

Kata kunci: blended learning, inkuiri terbimbing, kognitif, psikomotor

\begin{abstract}
The discovery of the concept of learning material independently can affect the cognitive and psychomotor abilities of participans. Observation results in SMAN 1 Karangtengah Demak indicate that learning is still teachercentered so the ability of students to find their own material concepts is still lacking,this causes low cognitive and psychomotor abilities. To avoid this, an appropriate learning model is needed, namely guided inquiry. Teachers have not yet applied internet-based learning that can form independent attitudes towards students, so internet-based learning such as blended learning is needed. His study aims to determine the effect of the application of guided inquiry based on blended learning on cognitive and psychomotor abilities of students of
\end{abstract}


class XI MIPA Karangtengah 1 High School in Demak Regency. The research method used is an experiment with sampling using cluster random sampling technique, obtained class XI MIPA 1 as the experimental class and XI MIPA 4 as the control class. Data retrieval is done by test and observation methods. Preliminary data analysis shows both classes are normally distributed and have the same variance. The average test results of the cognitive abilities of experimental class students were 71.14 and the control class was 67.35. The average psychomotor domain achievement based on experimental class practice observation sheet is $79.9 \%$ and the control class is 74.43\%. The influence of guiding inquiry based on blended learning on cognitive and psychomotor abilities through the test of the coefficient of determination was 10.62\%. Based on the results of the study it can be concluded that the application of the guided inquiry model based on blended learning has an effect on the cognitive and psychomotor abilities of students of class XI on the buffer solution material.

Keywords: blended learning, guided inquiry, cognitive, psychomotor

DOI: http://doi.org/10.15575/jtk.v4i2.5404

\section{PENDAHULUAN}

Perkembangan pendidikan dengan menerapkan kurikulum 2013 atau lebih dikenal sebagai kurikulum kompetensi yang merekomendasikan pendekatan saintifik dalam pembelajaran sebagai proses membangun tiga kompetensi diantaranya pengetahuan, keterampilan, dan sikap. Pendekatan saintifik memiliki empat model pembelajaran yaitu inquiry, discovery, problem based learning, dan project based learning (Sariono, 2013). Hasil penelitian dari Abdullah et al. (2017) menyatakan bahwa pembelajaran kooperatif dengan pendekatan saintifik dapat meningkatkan hasil belajar kognitif peserta didik. Pada proses pembelajaran, peserta didik diharapkan mampu menguasai ketiga kompetensi sebagai hasil dari proses belajar sehingga dapat menunjukkan kualitas yang seimbang terhadap pencapaian antara hard skill dan soft skill (Kusuma, 2013). Pendekatan saintifik ini jika diterapkan di sekolah, maka akan membentuk sikap ilmiah yang berkelanjutan dan peserta didik diharapkan dapat berperan aktif selama proses pembelajaran berlangsung.
Hasil observasi awal dan wawancara dengan guru kimia di SMAN 1 Karangtengah Kabupaten Demak mendapatkan data kemampuan kognitif peserta didik pada materi larutan penyangga tahun ajaran 2017/2018 masih tergolong rendah dengan rata-rata nilai ulangan harian sebesar 59,55 $(K K M \geq 70)$. Kemampuan ranah kognitif peserta didik yang belum mencapai KKM karena peserta didik masih kesulitan dalam menyelesaikan latihan soal yang diberikan oleh guru dan kurangnya pemahaman peserta didik dalam menyelesaikann soal. Peserta didik hanya terpaku pada hasil akhir saja dan kurang memahami langkah-langkah yang harus dikerjakan dalam menyelesaikan soal. Menurut Marsita et al. (2010) salah satu faktor yang menyebabkan peserta didik kesulitan dalam mempelajari materi kimia adalah penanaman konsep materi kimia yang kurang mendalam dan hal tersebut dapat diatasi dengan mengaitkan konsep-konsep dengan kehidupan sehari-hari.

Keterampilan psikomotor peserta didik kurang terlatih, karena tidak semua materi kimia dilengkapi dengan praktikum dan peserta didik hanya melakukan langkah kerja sesuai arahan guru yang telah dituliskan di papan 
tulis. Hal ini menyebabkan kemampuan psikomotor peserta didik masih tergolong rendah. Kegiatan praktikum merupakan sarana bagi peserta didik yang sangat berperan dalam meningkatkan keberhasilan proses pembelajaran karena dapat mendorong peserta didik untuk belajar secara aktif dalam merekonstruksi pemahaman konseptualnya (Duda, 2010). Penemuan konsep melalui menemukan sendiri akan menjadikan pembelajaran peserta didik lebih bermakna (meaningful learning), kebermaknaan ini akan berdampak pada peningkatan hasil belajar peserta didik (Budiada, 2011).

Guru juga belum menggunakan pembelajaran berbasis online yang sedang trend dan mengikuti perkembangan zaman sehingga dapat mempermudah guru dan peserta didik dalam proses pembelajaran di luar kelas. Salah satu materi kimia yang memerlukan pemahaman mendalam adalah materi larutan penyangga. Meningkatnya kemampuan kognitif dan psikomotor haruslah didukung dengan model pembelajaran dengan melibatkan peserta didik secara aktif dalam menemukan sendiri konsep suatu materi yang sangat sesuai digunakan untuk mengatasi kesulitan peserta didik dalam memahami materi pelajaran dan memberikan kemudahan kepada peserta didik dalam proses pembelajaran di dalam maupun di luar kelas.

Berdasarkan permasalahan, salah satu model pembelajaran yang dapat digunakan untuk meningkatkan kemampuan kognitif dan psikomotor peserta didik adalah dengan model pembelajaran inkuiri terbimbing berbasis blended learning.

Pembelajaran inkuiri dapat memberikan kesempatan dan dorongan alami pada peserta didik untuk melakukan eksplorasi (Putri dkk.,
2015). Pembelajaran berbasis internet yang dapat digunakan salah satunya adalah blended learning. Berdasarkan penelitian Wijanayu et al. (2018) peningkatan kemandirian belajar dari peserta didik diperoleh melalui pembelajaran berbasis blended learning. Tujuan dari penelitian ini adalah untuk mengetahui pengaruh penerapan inkuiri terbimbing berbasis blended learning terhadap kemampuan kognitif dan psikomotor peserta didik pada materi larutan penyangga.

\section{METODE PENELITIAN}

Penelitian ini merrupakan penelitian eksperimen. Penelitian dilaksanakan di SMAN 1 Karangtengah Kabupaten Demak, pada kelas XI MIPA semester genap tahun ajaran 2018/2019 pada materi larutan penyangga. Desain penelitian yang digunakan yaitu pretest-posttest control group design dengan pengambilan sampel menggunakan teknik cluster random sampling. Kelompok sampel yang digunakan pada penelitian ini adalah kelas XI MIPA 1 sebagai kelas eksperimen dan XI MIPA 4 sebagai kelas kontrol. Variabel pada kelas eksperimen diberikan perlakuan model inkuiri terbimbing berbasis blended learning sedangkan pada kelas kontrol diberikan perlakuan model ceramah berbasis blended learning. Variabel bebas pada penelitian ini adalah model inkuiri terbimbing berbasis blended learning, sedangkan variabel terikat yaitu kemampuan kognitif dan psikomotor.

Data yang diperoleh yaitu berupa data kuantitatif. Metode pengumpulan data yang digunakan dalam penelitian ini yaitu metode tes dan observasi. Instrumen pengumpulan data meliputi 20 soal pilihan ganda yang disusun berdasarkan indikator kompetensi dasar pada materi larutan penyangga dan lembar observasi praktikum. Instrumen lain 
yang digunakan pada penelitian ini berupa perangkat pendukung pembelajaran seperti silabus, RPP, dan LKPD yang disesuaikan dengan model inkuiri terbimbing. Teknik analisis data yang digunakan adalah uji normalitas, uji kesamaan dua varians, uji perbedaan rata-rata, penentuan korelasi biserial dan koefisien determinasi, reliabilitas soal tes kognitif, serta analisis lembar observasi praktikum, dan reliabilitas lembar observasi praktikum.

\section{HASIL DAN PEMBAHASAN}

Hasil penelitian meliputi nilai pretest-posttest kemampuan kognitif dan profil kemampuan psikomotor. Pembelajaran dibagi menjadi dua yaitu pembelajaran offline menggunakan model inkuiri terbimbing sedangakan pembelajaran online menggunakan aplikasi google classroom dalam mempermudah pembelajaran di luar kelas. Pembelajaran dengan model inkuiri terbimbing memberikan kesempatan kepada peserta didik agar dapat berdiskusi mencari dan menemukan jawaban sendiri dari rumusan masalah yang telah dibuat, sehingga diharapkan peserta didik dapat menumbuhkan sikap percaya diri dan dapat berperan aktif. Model pembelajaran inkuiri terbimbing adalah model yang memungkinkan peserta didik untuk bergerak dalam mengidentifikasi masalah, merumuskan masalah, hipotesis, pengumpulan data, verifikasi hasil, dan penarikan kesimpulan (Matthew dan Igharo, 2013).

Aktivitas pembelajaran online yang bisa disediakan guru melalui google classroom ini bervariasi. terdapat grup kelas online pada aplikasi google classroom, dimana peserta didik dapat masuk grup kelas online melalui kode yang telah diberikan oleh guru dengan syarat setiap peserta didik memiliki akun google mail. Google classroom mempermudah guru dan peserta didik dalam berinteraksi di luar jam pelajaran karena dapat diakses secara gratis dari android maupun PC. Aktivitas yang dilakukan peserta didik dalam pembelajaran online meliputi mengumpulkan tugas individu. pada setiap pertemuan maupun laporan praktikum, mengunduh materi pelajaran, dan melakukan diskusi online mereview kembali materi dan membahas soal posttest. Semua tugas yang telah diupload peserta didik secara otomatis akan tersimpan dalam google drive sehingga guru tidak perlu menyimpan softfile hasil pekerjaan peserta didik secara manual. $\mathrm{Hal}$ tersebut sejalan dengan penelitian Sriarunrasmee et al. (2015) yang menjelaskan bahwa kelebihan dari menggunakan internet dalam pembelajaran adalah peserta didik mampu mengakses pengetahuan lebih luas dan lebih dalam dan memberikan pengalaman baru sehingga menciptakan suasana belajar yang menyenangkan.

Tabel 1. Hasil Rekapitulasi Tes Kemampuan Kognitif Kelas Eksperimen dan Kelas Kontrol

\begin{tabular}{|c|c|c|c|c|}
\hline Data & Kelas & Rata-rata & Nilai Tertinggi & Nilai Terendah \\
\hline \multirow{2}{*}{ Pretest } & XI MIPA 1 & 46,29 & 55 & 35 \\
\cline { 2 - 5 } & XI MIPA 4 & 44,85 & 60 & 35 \\
\hline \multirow{2}{*}{ Posttest } & XI MIPA 1 & 71,14 & 95 & 40 \\
\cline { 2 - 5 } & XI MIPA 4 & 67,35 & 80 & 45 \\
\hline
\end{tabular}

Hasil rekapitulasi pretest dan posttest kelas eksperimen dan kelas kontrol dapat dilihat pada Tabel 1.
Data hasil kemampuan kognitif meliputi nilai pretest-posttest kelas eksperimen dan kelas kontrol. Hasil pretest digunakan untuk 
mengukur kemampuan kognitif peserta didik dari kelas kontrol maupun kelas eksperimen sebelum penelitian dilaksanakan.

Berdasarkan pada hasil penelitian diatas, ratarata nilai pretest kelas eksperimen lebih tinggi yaitu sebesar 46,29 dengan nilai tertinggi 55 dan terendah 35 , daripada rata-rata nilai pretest kelas kontrol adalah 44,85 dengan nilai tertinggi 60 dan terendah 35. Sedangkan ratarata nilai posttest kelas eksperimen juga lebih tinggi yaitu sebesar 71,14 dengan 27 peserta didik atau sebesar $77,14 \%$ dinyatakan tuntas dan sebanyak 8 peserta didik atau sebesar $22,86 \%$ dinyatakan belum tuntas karena belum memenuhi syarat $70 \leq K K M$. Selain itu rata-rata nilai posttest kelas kontrol lebih rendah yaitu sebesar 67,35 dengan 22 peserta didik atau sebesar $64,70 \%$ dinyatakan tuntas dan sebanyak 12 peserta didik atau sebesar $35,30 \%$ dinyatakan belum tuntas karena belum memenuhi syarat $70 \leq K K M$. Pembahasan di atas menunjukkan bahwa model inkuiri terbimbing berbasis blended learning mampu meningkatkan kemampuan kognitif pada peserta didik kelas eksperimen daripada penerapan model konvensional berbasis blended learning pada kelas kontrol.

Hasil penelitian sejalan dengan penelitian Yulianingsih dan Hadisaputro (2013) yang menjelaskan bahwa model inkuiri terbimbing efektif meningkatkan hasil belajar pada materi hidrokarbon dibuktikan dengan kelas eksperimen yang mencapai ketuntasan 93,94\% lebih tinggi daripada kelas kontrol yang hanya mencapai ketuntasan $78,79 \%$. Pembelajaran inkuiri terbimbing mampu meningkatkan kemampuan kognitif dan psikomotor karena pembelajaran yang dilakukan berpusat pada peserta didik dan memberikan kesempatan untuk mencari dan menemukan sendiri materi pelajaran.
Penelitian Wardani dkk. (2016) dan Wardani et al. (2013) menjelaskan bahwa pembelajaran inkuiri terbimbing dapat membuat peserta didik aktif dalam berbicara, karena peserta didik mengikuti pembelajaran dalam kelompok kecil yang harus berdiskusi menyelesaikan masalah dengan langkahlangkah tersebut. Uji yang digunakan dalam penelitian ini adalah uji korelasi biserial, uji koefisien determinasi, uji perbedaan rata-rata dan uji $N$-Gain. Uji korelasi digunakan untuk menguji pengaruh model inkuiri terbimbing berbasis blended learning terhadap kemampuan kognitif dan psikomotor. Uji korelasi yang digunakan adalah korelasi biserial dengan rumus :

$$
r_{b}=\frac{\left(\bar{Y}_{1}-\bar{Y}_{2}\right) p q}{u s_{y}}
$$

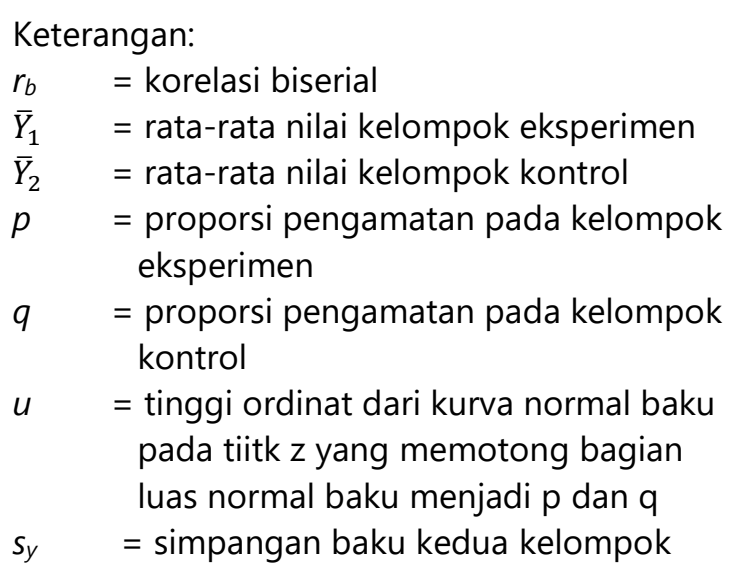

(Sudjana, 2005).

Uji koefisien determinasi (KD) digunakan untuk mengetahui besarnya pengaruh model inkuiri terbimbing berbasis blended learning terhadap kemampuan kognitif dan psikomotor. Rumus yang digunakan yaitu:

$$
K D=r_{b}^{2} \times 100 \%
$$

Keterangan :

$\mathrm{KD}=$ Koefisien Determinasi 
$\mathrm{r}_{\mathrm{b}}^{2} \quad=$ Indeks determinasi yang

diperoleh dari kuadrat $r_{b}$ koefisien

biserial

Uji perbedaan rata-rata digunakan untuk mengetahui perbedaan rata-rata kemampuan kognitif materi larutan penyangga antara kelas eksperimen dan kelas kontrol sebelum perlakuan dan setelah perlakuan pada materi larutan penyangga. Uji hipotesis menggunakan uji satu pihak kanan (Sudjana, 2005). Karena kedua kelas mempunyai varians yang sama, maka rumus yang digunakan adalah sebagai berikut :

$$
\begin{gathered}
t=\frac{\bar{x}_{1-} \bar{x}_{2}}{s \sqrt{\frac{1}{n_{1}}-\frac{1}{n_{2}}}} \\
\text { dengan } \\
S=\sqrt{\frac{\left(n_{1}-1\right) s_{1}^{2}+\left(n_{2}-1\right) s_{2}^{2}}{n_{1}+n_{2}-2}}
\end{gathered}
$$

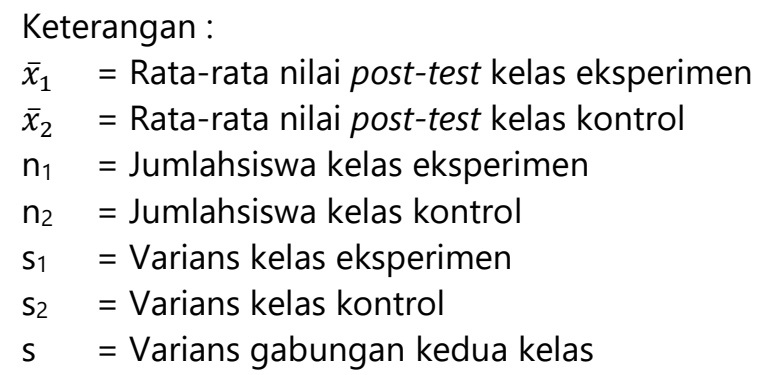

Uji N-Gain digunakan untuk mengetahui seberapa besar peningkatan kemampuan kognitif peserta didik setelah diberi perlakuan. Rumus yang digunakan yaitu:

$$
g=\frac{\text { rerata skor posttest-rerata skor pretest }}{\text { skor maksimum-rerata skor pretest }}
$$

Hasil uji pengaruh model inkuiri terbimbing berbasis blended learning untuk meningkatkan kemampuan kognitif dan psikomotor peserta didik disajikan pada Tabel 2, Tabel 3, dan Tabel 4.

Tabel 2. Uji Korelasi Biserial dan Koefisien Determinasi Data Posttest

\begin{tabular}{|c|c|c|c|}
\hline Data & Korelasi Biserial & Koefisien Determinasi & Kriteria \\
\hline $\begin{array}{c}\text { Nilai } \\
\text { Posttest }\end{array}$ & 0,326 & $10,62 \%$ & $\begin{array}{c}\text { model pembelajaran inkuiri terbimbing } \\
\text { berbasis blended memberikan pengaruh } \\
\text { rendah terhadap kemampuan kognitif }\end{array}$ \\
\hline
\end{tabular}

Berdasarkan hasil penelitian yang tersaji pada Tabel 2, nilai besarnya pengaruh penerapan inkuiri terbimbing berbasis blended learning ditunjukkan oleh uji korelasi biserial dengan rb bernilai 0,326 termasuk kategori rendah. Hal ini sejalan dengan hasil penelitian Sari dkk. (2017) bahwa inkuiri terbimbing berpengaruh terhadap hasil belajar kognitif dan psikomotor secara signifikan. Pengaruh penerapan inkuiri terbimbing berbasis blended learning juga ditunjukkan oleh uji koefisien determinasi (KD) data posttest diperoleh sebesar $10,62 \%$. Hal ini menunjukkan bahwa model pembelajaran pembelajaran inkuiri terbimbing berbasis blended learning mempengaruhi kemampuan kognitif.

Hasil penelitian sesuai dengan penelitian Fitriani et al. (2016) yang menyatakan bahwa model inkuiri terbimbing pada pembelajaran kimia efektif dalam meningkatkan hasil belajar dan keaktifan peserta didik. Hasil penilitian ini juga didukung oleh penelitian Yohana et al. (2018) yang menyatakan bahwa model inkuiri terbimbing pada pembelajaran kimia pada materi asam basa dapat meningkatkan hasil 
belajar kognitif peserta didik dibuktikan dengan rata-rata nilai kognitif sebesar 73 dan itu menunjukkan tingkat prestasi yang tinggi. Penelitian Rizqi et al. (2015) menjelaskan bahwa melalui pembelajaran berbasis blended learning, peserta didik mampu memahami dan menulis apa yang menjadi informasi dari soal, menuliskan apa yang ditanyakan serta dapat menemukan ide untuk menyelesaikan soal yang diberikan.

Tabel 3. Uji Perbedaan Rata-rata

\begin{tabular}{|c|c|c|c|}
\hline Data & t hitung & t tabel & Kriteria \\
\hline $\begin{array}{c}\text { Nilai } \\
\text { Posttest }\end{array}$ & 2,032 & 2,00 & $\begin{array}{r}\text { Rata-rata nilai posttest kemampuan kognitif peserta didik kelas } \\
\text { eksperimen lebih tinggi daripada kelas kontrol }\end{array}$ \\
\hline
\end{tabular}

Pengaruh penerapan inkuiri terbimbing berbasis blended learning juga ditunjukkan oleh hasil uji perbedaan rata-rata yang memperoleh hasil $\mathrm{t}$ hitung $>\mathrm{t}_{(0,05 ; 67)}$ yaitu $2,032>2,00$. Hal ini menunjukkan bahwa model pembelajaran pembelajaran inkuiri terbimbing berbasis blended learning mempengaruhi kemampuan kognitif. Hasil penelitian didukung oleh penelitian Hamidah (2018) yang menjelaskan model inkuiri terbimbing efektif untuk meningkatkan hasil belajar pada ranah kognitif dibuktikan dengan evaluasi pre-test dan post-test meningkat dengan rata-rata nilai pre-test 23,97 dan ratarata nilai post-test 81,47 . Penelitian Dewi dkk. (2013) yang menjelaskan bahwa pembelajaran inkuiri terbimbing berpengaruh dalam meningkatkan hasil belajar IPA dan sikap ilmiah peserta didik

Tabel 4. Uji N-Gain Data Posttest

\begin{tabular}{|c|c|c|c|c|}
\hline Kelompok & Kelas & N & N-Gain & Keterangan \\
\hline Eksperimen & XI MIPA 1 & 36 & 0,73 & Tinggi \\
\hline Kontrol & XI MIPA 4 & 35 & 0,64 & Sedang \\
\hline
\end{tabular}

Perhitungan $N$-Gain untuk mengetahui peningkatan kemampuan kognitif setelah penerapan model inkuiri terbimbing berbasis blended learning. Pada Tabel 4, harga N-Gain kemampuan kognitif untuk kelas eksperimen sebesar 0,73 (kategori tinggi) Sehingga dapat disimpulkan bahwa peningkatan kemampuan kognitif kelas eksperimen yang menggunakan inkuiri terbimbing berbasis blended learning sebesar 0,73 . Hasil penelitian didukung oleh penelitian Novilia et al. (2016) juga menyatakan bahwa model inkuiri terbimbing efektif untuk meningkatkan hasil belajar kognitif peserta didik ditunjukkan dengan skor $N$-Gain nilai pretest dan posttest kemampuan kognitif peserta didik sebesar 0,688 dikategorikan sedang.
Reliabilitas dari hasil posttest kelas eksperimen diperoleh sebesar 0,64. Hasil analisis tersebut menunjukkan bahwa soal dinyatakan tidak reliabel karena belum memenuhi syarat 0,70 $\leq$ $r_{11}$. Reliabilitas dari hasil posttest kelas kontrol diperoleh sebesar 0,53. Hasil analisis tersebut menunjukkan bahwa soal dinyatakan tidak reliabel karena belum memenuhi syarat 0,70 $\leq$ $r_{11}$.

Kemampuan psikomotor peserta didik pada penelitian ini juga dilakukan dengan instrumen non tes yaitu berupa lembar observasi kegiatan praktikum. Praktikum dilaksanakan pada pertemuan kedua di kelas eksperimen maupun kelas kontrol. Observasi 
praktikum yang dilakukan melibatkan dua orang observer yang selanjutnya dibagi-bagi memegang tiap kelompok dari peserta didik. Terdapat 3 indikator kemampuan psikomotor, meliputi, 1) tahap persiapan, 2) proses praktikum, 3) pelaksanaan akhir setelah praktikum. Persentase observasi praktikum pada kelas eksperimen dan kelas kontrol dapat dilihat pada Gambar 1.

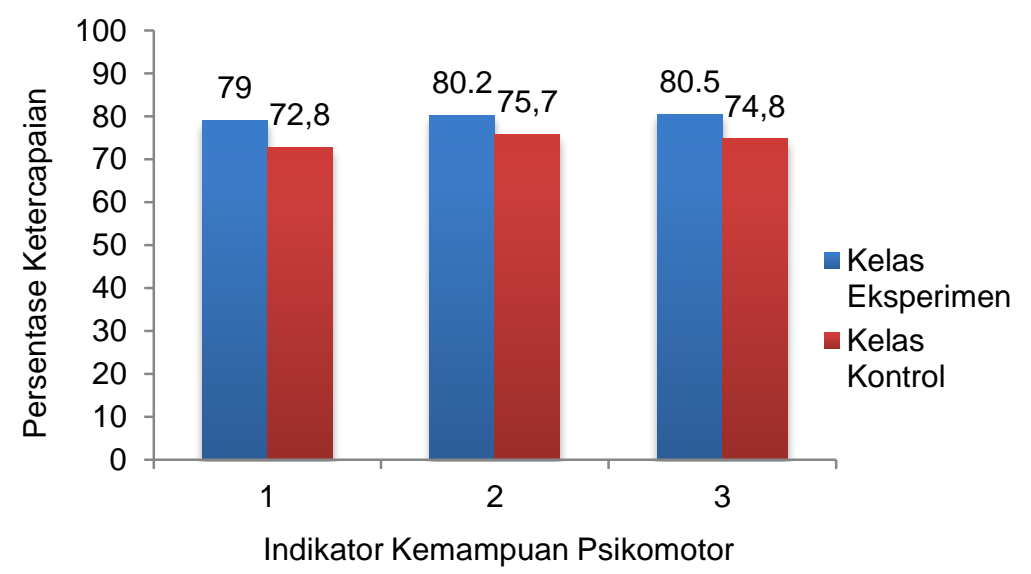

Gambar 1. Persentase Kemampuan Psikomotor Per Indikator Kelas Eksperimen dan Kelas Kontrol

Berdasarkan Gambar 1, diperoleh rata-rata persentase ketercapaian indikator kemampuan psikomotor kelas eksperimen yaitu $79 \%$ untuk tahap persiapan, $80,2 \%$ untuk proses praktikum, dan 80,5\% untuk pelaksanaan akhir setelah praktikum. rata-rata persentase ketercapaian indikator kemampuan psikomotor kelas kontrol yaitu 72,8\% untuk tahap persiapan, 75,7\% untuk proses praktikum, dan $74,8 \%$ untuk pelaksanaan akhir setelah praktikum. Hasil analisis diatas menunjukkan bahwa bahwa penerapan model inkuiri terbimbing berbasis blended learning pada kelas eksperimen memperoleh presentase kemampuan psikomotor berdasarkan lembar observasi praktikum lebih tinggi daripada kelas kontrol yang menggunakan model konvensional berbasis blended learning. Hasil penelitian sejalan dengan penelitian Sari dkk. (2017) yang menjelaskan bahwa pembelajaran inkuiri terbimbing berpendekatan multiple intelligences berpengaruh terhadap hasil belajar ranah keterampilan peserta didik dibuktikan kelas eksperimen memiliki lima aspek yang berkriteria tinggi, sedangkan kelas kontrol memiliki tiga aspek berkriteria tinggi. Profil kemampuan psikomotor kelas eksperimen dan kelas kontrol dapat dilihat pada Gambar 2.

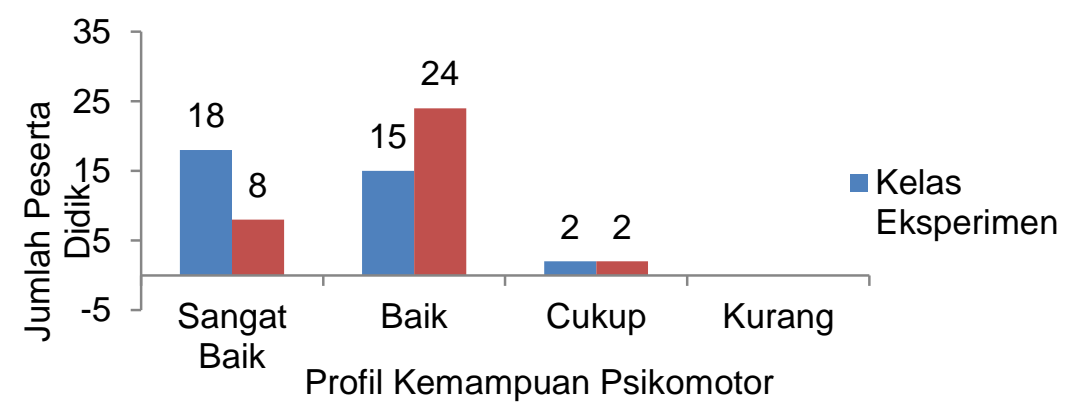

Gambar 2. Profil Kemampuan Psikomotor Kelas Eksperimen Dan Kelas Kontrol 
Berdasarkan Gambar 2, kelas eksperimen memperoleh profil kemampuan psikomotor yaitu 18 peserta didik kategori sangat baik, 15 peserta didik kategori baik, tidak ada peserta didik kategori cukup, dan 2 peserta didik kategori kurang. Pada kelas kontrol memperoleh profil kemampuan psikomotor yaitu 8 peserta didik kategori sangat baik, 24 peserta didik kategori baik, tidak ada peserta didik kategori cukup, dan 2 peserta didik kategori kurang. Hasil penelitian sejalan dengan penelitian Hamidah (2018) yang menjelaskan bahwa inkuiri terbimbing efektif untuk meningkatkan kemampuan psikomotor peserta didik dibuktikan dengan rata-rata aspek psikomotorik sebesar 80,3 dengan kriteria baik.

Laporan praktikum peserta didik diunggah melalui aplikasi google classroom, laporan praktikum dikumpulkan tiap kelompok. Reliabilitas dari hasil analisis lembar observasi praktikum kelas eksperimen diperoleh sebesar 0,829 . Hasil analisis tersebut menunjukkan bahwa lembar observasi dinyatakan reliabel karena memenuhi syarat 0,70 $\leq r_{11}$. Reliabilitas dari hasil analisis lembar observasi praktikum kelas kontrol diperoleh sebesar 0,792. Hasil analisis tersebut menunjukkan bahwa lembar observasi dinyatakan reliabel karena memenuhi syarat $0,70 \leq r_{11}$.

Hasil penelitian menunjukkan bahwa kelas eksperimen memperoleh hasil yang lebih tinggi daripada kelas kontrol. Hal tersebut dikarenakan model inkuiri terbimbing dapat membuat peserta didik lebih aktif dan memberikan motivasi belajar agar dapat memahami dan menerapkan konsep yang ada dalam pembelajaran. Model pembelajaran inkuiri terbimbing ini juga memberi kesempatan lebih banyak kepada peserta didik untuk merefleksikan pembelajaran, mendapat pemahaman yang lebih dalam, sehingga mampu mengoptimalkan kemampuan kognitif dan psikomotor. Peserta didik dibimbing untuk menemukan sendiri suatu konsep berdasarkan fenomena yang bekaitan dengan larutan penyangga. Contoh penerapan larutan penyangga dalam kehidupan sehari-hari dapat mempermudah proses pembelajaran inkuiri terbimbing. Dari kegiatan tersebut, peran guru juga dibutuhkan untuk mengarahkan peserta didik agar memperoleh konsep materi yang tepat dan memberikan penguatan atas konsep tersebut. Model inkuiri terbimbing pada pembelajaran materi larutan penyangga menjadikan pembelajaran menjadi lebih bermakna bagi peserta didik (Budiada, 2011).

Pembelajaran berbasis blended learning yang menggunakan aplikasi google classroom digunakan untuk mengumpulkan tugas individu pada setiap pertemuan maupun laporan praktikum secara online, mengunduh materi pelajaran, dan melakukan diskusi online seperti mereview kembali materi dan pembahasan soal posttest. Hal tersebut mempermudah guru dan peserta didik agar dapat berinteraksi di luar jam pelajaran, sehingga peserta didik mampu mengembangkan kemampuan kognitif dan psikomotor yang dimiliki. Hasil penelitian ini juga didukung oleh penelitian Suhandi dkk. ( 2009) menjelaskan bahwa pembelajaran berbasis teknologi dapat meningkatkan efektivitas pembelajaran dan pemahaman Jurnal Tadris Kimiya 3, 2 (Desember 2018): 189-201

This is an open access article under CC-BY-SA license (https://creativecommons.org/licenses/by-sa/4.0/) 
konsep sehingga dapat meningkatkan hasil belajar ranah kognitif peserta didik. Manggabarani et al. (2016) menyatakan bahwa rerata skor hasil belajar peserta didik yang mengikuti blended learning lebih tinggi dari rerata skor hasil belajar peserta didik yang mengikuti pembelajaran langsung.

Meskipun nilai pretest tertinggi kelas eksperimen lebih rendah yaitu 55 daripada kelas kontrol yang memperoleh nilai tertinggi 60 dan nilai posttest terendah kelas kontrol lebih tinggi yaitu 45 daripada kelas eksperimen yang memperoleh nilai terendah 40, hal tersebut dikarenakan kelas eksperimen kurang teliti dan cermat dalam memahami soal. Berdasarkan hasil penelitian pada kemampuan kognitif dan psikomotor peserta didik kelas eksperimen lebih tinggi daripada kelas kontrol. Hal ini membuktikan bahwa penerapan model inkuiri terbimbing berbasis blended learning lebih baik dibandingkan model konvensional berbasis blended learning. Hasil penelitian sejalan dengan penelitian Fitriani et al. (2016) menyatakan bahwa model inkuiri terbimbing pada pembelajaran kimia efektif dalam meningkatkan hasil belajar dan keaktifan peserta didik. Wijanayu et al. (2018) menyatakan bahwa peningkatan pemahaman konsep peserta didik yang mengikuti metode blended learning lebih tinggi daripada peserta didik yang mengikuti pembelajaran diskusi dan tanya jawab. Pelaksanaan diskusi kelompok yang memadukan model inkuiri terbimbing dengan blended learning yang tidak hanya dilakukan saat pembelajaran di kelas namun juga dilakukan di luar kelas secara online dan ini terbukti sangat membantu peserta didik dalam memahami materi yang belum dipahami saat pembelajaran di kelas dan meningkatkan interaksi peserta didik dalam proses pembelajaran, sehingga peserta didik dapat meningkatkan kemampuan ranah kognitif maupun psikomotornya (Donnelly, 2012).

Pengaruh penerapan model inkuiri terbimbing berbasis blended learning dalam meningkatkan kemampuan kognitif dan psikomotor sebesar $10,62 \%$ tergolong rendah, menunjukkan bahwa masih terdapat kelemahan pada penerapannnya. Kendala yang dialami peserta didik antara lain keterbatasan waktu dalam pelaksanaan pembelajaran model inkuiri terbimbing berbasis blended learning dan koneksi yang tidak stabil sehingga beberapa peserta didik tidak bisa menggunakan salah satu fitur pada google classroom. Hal ini sesuai dengan yang disampaikan Pranoto et al. (2014) bahwa proses pembelajaran dengan model blended learning akan terganggu jika ada permasalahan pada server yang menjadikan sinyal dari hotspot area terlalu lemah. Meskipun memiliki kelemahan pada koneksi, blended learning memberikan pengalaman belajar yang unik kepada peserta didik karena berisikan proses pembelajaran campuran antara tatap muka yaitu menggunakan metode inkuiri terbimbing dengan online sehingga peserta didik dapat memaksimalkan kemampuan yang dimiliki (Garrison dan Vaughan, 2008).

Dalam pelaksanaan model inkuiri terbimbing terdapat beberapa kendala diantaranya: (1) peserta didik belum terbiasa menggunakan model inkuiri terbimbing sehingga guru agak sulit dalam menerapkan model ini; (2) penggunaan model inkuiri terbimbing belum optimal karena waktu pelaksanaan hanya tiga 
pertemuan yang dinilai terbatas; (3) Pada saat pembelajaran berlangsung di setiap pertemuan ada beberapa peserta didik yang tidak mengikuti pembelajaran baik karena absen sekolah atau karena dispensasi. Hal tersebut sejalan dengan pernyataan yang dikemukakan oleh Prambudi (2010) yaitu beberapa kelemahan pembelajaran inkuiri terbimbing meliputi: (1) model inkuiri terbimbing sulit dalam merencanakan pembelajaran karena terbentur dengan kebiasaan peserta didik dalam belajar; (2) dalam mengimplementasikan model inkuiri terbimbing memerlukan waktu yang panjang sehingga guru sulit menyesuaikan dengan waktu yang telah di tentukan.

\section{KESIMPULAN}

Berdasarkan penelitian yang telah dilakukan, penerapan model inkuiri terbimbing berbasis blended learning berpengaruh terhadap kemampuan kognitif dan psikomotor peserta didik kelas XI pada materi larutan penyangga. Diperoleh rata-rata hasil tes kemampuan kognitif peserta didik kelas eksperimen sebesar 71,14 dan kelas kontrol sebesar 67,35. Besarnya pengaruh model inkuiri terbimbing berbasis blended learning melaui uji koefisien determinasi yakni sebesar 10,62\% dengan hasil uji koefisien korelasi biserial sebesar 0,326 dengan kategori rendah. Rata-rata ketercapaian ranah psikomotor berdasarkan lembar observasi praktikum kelas eksperimen sebesar $79,9 \%$ dan kelas kontrol $74,43 \%$ 


\section{DAFTAR PUSTAKA}

Abdullah, N.S., Mulbar, U., \& Minggi, I. (2017). The Quality Improvement of Matematics Learning Through The Implementation of Cooperative Learning Model With Scirntific Approach to Class. Jurnal Daya Matematis, 5(1), 1-13.

Budiada, I.W. (2011). Pengaruh Penerapan Model Pembelajarn Inkuiri Terbimbing Berbasis Asesmen Portofolio terhadap Hasil Belajar Kimia Siswa Kelas X Ditinjau dari Adversity Quotient. Jurnal Pasca Undiksha, 1(2), 1-16.

Dewi, N.L., Nyoman, D., \& Wayan, S. (2013). Pengaruh Model Pembelajaran Inkuiri Terbimbing terhadap Sikap Ilmiah dan Hasil belajar IPA. Jurnal Program Pascasarjana Universitas Pendidikan Ganesha, 3(4), 400-413.

Donnelly, R. (2012). Harmonizing Technology With Interaftion In Blended Learning. Dublin Institute of Technology: Computers and Education, 54(2), 350-359.

Duda, H.J. (2010). Pembelajaran Berbasis Praktikum dan Asesmennya pada Sistem Ekskresi untuk Meningkatkan Kemampuan Berpikir Kritis Siswa Kelas XI, VOX Edukasi, 1(2), 29-39.

Fitriani, N. R., Widiyatmoko, \& Khusniati. (2016). The Effectiveness Of CTL Model Guided Inquiri-Based in The Topic of Chemicals In Daily Life to Improve Students' Learning Outcomes And Activeness. Jurnal Pendidikan IPA Indonesia, 5(2), 278-283.

Garrison, D.R., \& Vaughan, N.D. (2008). Blended Learning in Higher Education: Framework, Principles, and Guidelines. San Francisco: Jossey-Bass.
Hamidah, N. (2018). Efektifitas Lembar Kerja Peserta Didik Berbasis Inkuiri Terbimbing untuk Meningkatkan Hasil Belajar Siswa. Jurnal Inovasi Pendidikan Kimia, 12(2), 2212-2223.

Kusuma, D. C. (2013). Analisis komponenkomponen pengembangan Kurikulum 2013 pada bahan uji publik Kurikulum 2013. Jurnal Analisis KomponenKomponen Pengembangan Kurikulum, 5 , 1-21.

Manggabarani, A.F., Sugiarti, \& Masri, M. (2016). Pengaruh Model Pembelajaran Blended Learning Terhadap Motivasi Dan Hasil Belajar Siswa Kelas X SMA Negeri 1 Pitumpanua Kab. Wajo (Studi Pada Materi Pokok Sistem Periodik Unsur) The Effect Of " Blended Learning " Models On Motivation And Student Achieve. Jurnal Chemical, 17(2), 83-93.

Marsita, R.A., Sigit P. \& Ersanghono K. 2010. Analisis Kesulitan Belajar Kimia Siswa SMA dalam Memahami Materi Larutan Penyangga dengan menggunakan TwoTier Multiple Choice Diagnostic Instrument. Jurnal Inovasi Pendidikan Kimia, 4(1), 512-520.

Matthew, B.M., dan Igharo, O.K. (2013). A study on the effects of guided inquiry teaching method on students achievement in logic. International Researcher, 2(1), 134-140.

Novilia, L., Srini, \& Fauziah, F. (2016). The Effectiveness of Colloid Module Based on Guided Inquiry Approach to Increase Student's Cofnitive Learning Outcomes. International Journal of Education, 9(1), 17-28.

Prambudi, K. (2010). Model Inkuiri Terbimbing. Jakarta: kencana Prenada Media.

Jurnal Tadris Kimiya 3, 2 (Desember 2018): 189-201

This is an open access article under CC-BY-SA license (https://creativecommons.org/licenses/by-sa/4.0/) 
Pranoto, E., Suciati, \& Sunarno, W. (2014). The Effectiveness of the Implementation of Problem Based Learning (PBL), Blended Learning (BL) Models, and Their Integrity of Learning Outcomes Viewed from the Evaluation Ability and Student Creativity The Effectiveness of Implementation of Problem Based Learning (PBL). Bioedukasi, 7(1), 44-50.

Putri, Y., Suratno \& Asyiah, I.N. (2015). Pengaruh Model Pembelajaran Inkuiri Terbimbing (Guided Inquiry) dengan Menggunakan Metode Eksperimen terhadap Aktivitas dan Hasil Belajar IPABiologi Siswa Kelas VIII SMP Negeri 2 Maesan Bondowoso. Jurnal Pendidikan Biologi, 4(2), 163-172.

Rizqi, A.A., Hardi, S., \& Sudarmin. (2015). Mathematical Communication Capability Analysis Viewed From Student Confidence Through Blended Learning. Unnes Journal of Mathematics Education Research, 17-23.

Sari, A.A., Subiyanto, H., \& Sri, N. (2017). Penerapan Inkuiri Terbimbing Berpendekatan Multiple Intelligences Terhadap Hasil Belajar Kimia. Chemistry in Education, 6(2), 57-62.

Sariono, (2013). Kurikulum 2013: Kurikulum Generasi Emas. E-Jurnal Dinas Pendidikan Kota Surabaya, 3, 1-9.

Sriarunrasmee, J., Wawta, T., \& Rattiya, P. M. (2015). Blended Learning Supporting Self-Directed Learning and Communication Skills of Srinakharinwirot University 's First Year Students. Procedia - Social and Behavioral Sciences, 197(2), 1564-1569.

Sudjana. (2005). Metoda Statistika. Bandung:

PT. Tarsito Bandung.
Suhandi, A., Sinaga, P., Kaniawati I., \& Suhendi, E. (2009). Efektivitas Penggunaan Media Simulasi Virtual pada Pendekaran Pembelajaran Suharyadi, Anna P. \& Hernani. 2013. Pengembangan Buku Ajar Berbasis Kontekstual pada Pokok Bahasan Asam dan Basa. Jurnal Riset dan Praktik Pendidikan Kimia, 1(5), 60-68.

Wardani, S., Santi, S., \& Kasmadi, I. S. (2016). Pengaruh Pembelajaran Inkuiri Terbimbing Terhadap Pemahaman Konsep dan Oral Activities pada Materi Pokok Reaksi Reduksi dan Oksidasi. Jurnal Inovasi Pendidikan Kimia, 10(2), 1743-1750.

Wardani, S., Asep, K., \& Anna, P. (2013). Java Culture Internalization in Elektrometri Learning Based Inquiry Laboratory Activities to Increase Inter-Intrapersonal Intelligence. International Journal of Science and Research (IJSR), 2(5), 417-421.

Wijanayu, A., Wahyu, H., \& Wiwi, I. (2018). Blended Learning Method Based on Quipper School to Improve Concepts Understanding and Independence Learning. Journal of Primary Education, 7(1), 88-95.

Yulianingsih, U., \& Hadisaputro, S. (2013). Keefektifan Pendekatan Student Centered Learning dengan Inkuiri Terbimbing untuk Meningkatkan Hasil Belajar. Chemistry in Education, 2(2), 149155.

Yohana, I., Sudarmin., Sri, S., \& Norasikin, S. (2018). The Generic Skill Profile of Fourth Grade Students on Acid and Base Topic in Guided Inquiry Learning Model. International Journal of Active Learning, 3(2), 110-121. 